\title{
The relationship between preoperative $T$ helper cytokines in the ileal mucosa and the pathogenesis of pouchitis
}

Takahito Kitajima* (D), Yoshiki Okita, Mikio Kawamura, Satoru Kondo, Yuji Toiyama, Keiichi Uchida and Masato Kusunoki

\begin{abstract}
Background: Although the etiology of pouchitis remains unknown, inflammatory cytokines are significantly associated with the pathogenesis of pouchitis. The cytokine responses that characterize inflammatory bowel diseases (IBD) are key pathogenic components of the disease. Although cytokine profiles in the colonic mucosa have been investigated in experimental colitis models or IBD patients, cytokine profiles in the ileal mucosa at colectomy have been rarely assessed.

Aim: To assess the relationship between pouchitis and T helper (Th) cytokines in the ileal mucosa collected at the time of colectomy and pouch construction.

Methods: This retrospective study involved 68 consecutive patients from January 2004 to May 2011 who underwent ileal pouch-anal anastomosis for ulcerative colitis. Samples were obtained from the terminal ileum of resected specimens at time of total colectomy or subtotal colectomy. mRNA expression levels of Th cytokines (IFNY, IL-23A, IL-5, IL-13 and IL-17A) were determined.

Results: Forty of 68 patients (58.8\%) developed pouchitis. There was no association between IL-23A expression levels and incidence of pouchitis $(p=0.301)$. Patients with elevated IFN- $\gamma$ had a significantly higher incidence of pouchitis compared with low IFN- $\gamma$ patients $(p=0.043)$. Univariate analysis demonstrated a total dose of prednisolone $>7000 \mathrm{mg}$ administered before colectomy $(p=0.04)$ and high IFN- $\gamma$ expression $(p=0.02)$ were significant risk factors for pouchitis onset. In multivariate analysis, elevated IFN- $\gamma$ messenger(m)RNA levels were significantly associated with pouchitis onset $(p=0.03)$.
\end{abstract}

Conclusion: IFN- $\gamma$ expression in the normal ileal mucosa at the time of colectomy may be an important factor in the pathophysiology of pouchitis.

Keywords: Ulcerative colitis, Pouchitis, Cytokine, IFN- - , IBD

\footnotetext{
*Correspondence: t-kitajima@clin.medic.mie-u.ac.jp

Department of Gastrointestinal and Pediatric Surgery, Division of Reparative Medicine, Institute of Life Sciences, Mie University Graduate School of

Medicine, 2-174 Edobashi, Tsu, Mie 514-8507, Japan
}

(c) The Author(s). 2020 Open Access This article is licensed under a Creative Commons Attribution 4.0 International License, which permits use, sharing, adaptation, distribution and reproduction in any medium or format, as long as you give appropriate credit to the original author(s) and the source, provide a link to the Creative Commons licence, and indicate if changes were made. The images or other third party material in this article are included in the article's Creative Commons licence, unless indicated otherwise in a credit line to the material. If material is not included in the article's Creative Commons licence and your intended use is not permitted by statutory regulation or exceeds the permitted use, you will need to obtain permission directly from the copyright holder. To view a copy of this licence, visit http://creativecommons.org/licenses/by/4.0/. The Creative Commons Public Domain Dedication waiver (http://creativecommons.org/publicdomain/zero/1.0/) applies to the data made available in this article, unless otherwise stated in a credit line to the data. 


\section{Background}

Restorative proctocolectomy and ileal pouch anal anastomosis (IPAA) have been established as standard surgical treatment methods for the management of ulcerative colitis (UC). Pouchitis, a nonspecific inflammatory condition of the ileal pouch, is a well-known complication in patients who undergo IPAA. Pouchitis is defined as nonspecific inflammation developing after intestinal continuity of IPAA. The incidence of pouchitis is $40-70 \%$ in UC patients who receive IPAA [1-3]. Although the immunopathogenesis of pouchitis is unclear, there are two major mechanisms associated with pouchitis: microbial dysbiosis and abnormal immune responses [4]. Whether inflammation of the pouch mucosa represents a recurrence of immune mechanisms in UC or a new form of inflammatory bowel disease (IBD) remains a topic of discussion.

Cytokine responses that characterize IBD are key pathogenic components of the disease. Cytokine responses play key roles in the initiation, evolution, maintenance, and resolution of inflammation. Classically, two types of cytokine responses, determined by $\mathrm{T}$-cell differentiation, have been described [5]: T-helper cell (Th)1 and Th2. Th1, characterized by the production of interferon (IFN) $-\gamma$ mediates Crohn's disease (CD) [6]. Th2 responses, characterized by the production of interleukin (IL) -5 and IL-13 as well as normal IFN- $\gamma$, mediate UC $[7,8]$. In addition to these two Th cell types, the recently described Th17 cells, producing IL-17 and IL-23, were reported as a third component of Th cells in various autoimmune disease models [9-11]. IL-23 is a newly discovered cytokine that has a role in the maintenance and/ or expansion of Th17 cells $[12,13]$. In the mucosa of IBD, Th17 cells have been proposed to play a key role in intestinal inflammation $[14,15]$. Th1 cytokines as well as those secreted from Th17 cells might be associated with CD [14]. Olsen et al. reported that the gene expression levels of IL-17A, IL-23 and IFN- $\gamma$ correlated with the grade of inflammation in UC, and that IL-17A and IL-23 had a role in mediating inflammation in both forms of IBD [16]. Clarification of these complex networks of Th cytokines might lead to the identification of novel targets for the diagnosis and treatment of CD and UC.

Mucosal concentrations of proinflammatory cytokines including IL-1ß, IL-6 and IL-8 were increased in pouchitis similar to UC $[17,18]$. However, cytokine profiles in the ileal mucosa at the time of colectomy have been rarely assessed. Investigating these cytokines in the ileal mucosa might help diagnose the subsequent onset of pouchitis. To the best of our knowledge, no study has examined Th cytokine profiles in ileal mucosa obtained at the time of total colectomy in patients with UC. This study evaluated Th cytokines in the ileal mucosa from UC patients at the time of total colectomy, and tested the predictive value of these cytokines for the onset of pouchitis.

\section{Methods \\ Patients and specimens}

From 2004 to 2011, this study included 183 patients who underwent IPAA in our institution. One hundred fifteen patients excluded for the following reasons: unable to obtain the frozen tissue samples of ileal mucosa because of emergency surgery (subtotal colectomy) $(n=65)$, poor quality of $\operatorname{samples}(n=12)$ and lost to follow-up $(n=38)$. In total, frozen tissue samples of ileal mucosa were obtained from 68 patients who underwent IPAA in our institution. Samples were obtained from the terminal ileum of resected specimens at time of total colectomy or subtotal colectomy. Patients with obvious backwash ileitis were excluded. Samples were soaked in RNA later and stored at $-80^{\circ} \mathrm{C}$ until RNA extraction. The protocol for this research project has been approved by a suitably constituted Ethics Committee of the institution and it conforms to the provisions of the Declaration of Helsinki. All informed consent was obtained from the subjects and guardians.

\section{Surgical procedure and diagnosis of pouchitis}

All patients underwent IPAA and routinely performed endoscopy each year after stoma closure. In addition, patients with suspected pouchitis were assessed by endoscopic assessments. Patients with pouchitis were diagnosed by a modified Pouchitis Disease Activity Index (mPDAI) score $\geq 5$ [19]. Patients with CD of pouch were diagnosed with granulomas, stenosing, fistulising and inflammatory during follow-up $[20,21]$. Patients with CD of the pouch and Secondary pouchitis (pouch ischemia, anastomotic stricture, pelvic sepsis, Cytomegalovirus infection, Clostridium difficile infection, and regular use of nonsteroidal anti-inflammatory drugs) were excluded. The onset of pouchitis was defined as the time from stoma closure to clinical and endoscopic diagnosis at the first episode. Acute antibiotic-responsive pouchitis (ADP) was defined as episodes of symptomatic pouch inflammation occurring fewer than 4 times per year with symptomatic response to a 2-week course of a single antibiotic such as ciprofloxacin. Chronic antibioticrefractory pouchitis (CARP) included patients with greater than 4 episodes of symptomatic pouch inflammation per year, individuals who require continuous antibiotic therapy to maintain symptom remission, or patients whose symptoms were refractory to antibiotic therapy [22].

\section{RNA extraction and cDNA synthesis}

Ileal mucosa was homogenized with a Mixer Mill MM 300 homogenizer (Qiagen, Chatsworth, CA, USA). Total 
RNA was isolated using a RNeasy Mini Kit (Qiagen) according to the manufacturer's instructions. Then, purity and concentration of RNA was estimated with NanoDrop. Pure RNA was obtained with a A260/A280 ratio of 2.0-2.2. Degraded RNA could be detected with different ratio. cDNA was synthesized from $5.0 \mathrm{mg}$ total RNA with random hexamer primers and Superscript III reverse transcriptase (Invitrogen, Carlsbad, CA) according to the manufacturer's instructions.

\section{Quantitative reverse transcription-polymerase chain reaction (qRT-PCR)}

qRT-PCR analysis was performed using the TaqMan universal PCR Master Mix (Applied Biosystems, Foster City, CA, USA). We investigated the mRNA expression of 5 cytokines in the terminal ileum focusing on Th2 responses (IL-5, IL-6, IL-13, IL-17A and IL-23), and IFN$\gamma$. The relative abundance of target transcripts was measured using TaqMan probes (Applied Biosystems, Foster City, CA, USA) for IFN- $\gamma$ (Assay ID: Hs00989291_m1), IL-5 (Assay ID: Hs01548712_g1), IL13 (Assay ID: Hs00174379_m1), IL-17A (Assay ID: Hs001743883_m1), and IL-23A (Assay ID: Hs00900828_ g1). Glyceraldehyde-3-phosphate dehydrogenase: GAPD $H$ (Assay ID, Hs02758991_g1; Applied Biosystems) was measured as an internal housekeeping gene. cDNA was amplified and quantified using Applied Biosystems StepOne Plus Real-Time PCR System and analyzed by Software version 2.2.2 (Applied Biosystems).

\section{Quantification of the relative expression levels of Th cytokines}

Relative gene expression was determined using the standard curve method. Standard curves and line equations were generated using five-fold serially diluted solutions of cDNA generated by the reverse transcription of qPCR Human Reference Total RNA (Clontech, Mountain View, CA, USA). All standard curves were linear in the analyzed range with an acceptable correlation coefficient $\left(R^{2}\right)$. Target gene expression was calculated from the standard curve followed by the quantitative normalization of cDNA in each sample using GAPDH as an internal control. Assays were performed in duplicate for each sample and the mean value was used for analysis.

\section{Statistical analysis}

Results were expressed as median values (interquartile range). The cutoff value of each continuous variable was determined by the median value. Comparisons were performed using non-parametric Wilcoxon signed-rank test for continuous variables. Cumulative incidence of pouchitis was evaluated by the Kaplan-Meier method. Differences between two groups were determined by the log-rank test. Cox proportional hazard regression analysis was used to evaluate the independent influence of factors on the onset of pouchitis. All statistical analyses were carried out using JMP 10 for Windows software (SAS Institute, Cary, NC, USA). Two-sided $p$-values < 0.05 were considered statistically significant.

\section{Results}

\section{Patient characteristics}

Sixty-eight patients (male/female; 39/29, median age; 32 years (11-62 years)) were enrolled in this study. The median follow-up period was 40 months (0-117 months). Among these patients, 40 (58.8\%) developed pouchitis (Fig. 1). Patient characteristics are shown in Table 1.

\section{Expression levels of Th cytokines}

The mRNA expression levels of Th cytokines (IFN- $\gamma$, IL23A, IL-5, IL-13 and IL-17A) were calculated. More than half of the samples were below the level of detection in IL-5, IL-13 and IL-17A assays. These cytokines were excluded from further analysis.

\section{Cumulative incidence of pouchitis after IPAA according to mRNA levels of Th cytokines}

The cumulative incidence of pouchitis according to the expression levels of IFN- $\gamma$ and IL-23A are shown in Fig. 2. Although there was no association between IL23A expression levels and the incidence of pouchitis $(p=0.301)$, patients with elevated IFN- $\gamma$ had a significantly higher incidence of pouchitis than those with low levels of IFN- $\gamma(p=0.043)$. Because only IFN- $\gamma$ was associated with the onset of pouchitis, we focused the rest of our study on IFN- $\gamma$.

\section{Relationship between IFN- $\gamma$ and preoperative clinicopathologic data}

The relationship between pouchitis and preoperative clinicopathologic factors is shown in Table 2. There was a significant difference between IFN- $\gamma$ level and severity of colitis, and patients with elevated C-reactive protein had a trend for higher IFN- $\gamma$ mRNA levels. However, there was no correlation between IFN- $\gamma$ and type of pouchitis. According to univariate analysis, a total dose of prednisolone $>7000 \mathrm{mg}$ administered before colectomy and IFN- $\gamma$ were identified as significant risk factors for the onset of pouchitis (Table 3). In addition, multivariate analysis showed that elevated IFN- $\gamma$ mRNA levels were significantly associated with the onset of pouchitis.

\section{Discussion}

The etiology of pouchitis is unknown, but numerous risk factors have been identified. Increased incidence of pouchitis in patients with extraintestinal manifestations [23-27], younger age [27], shorter disease duration [2], 


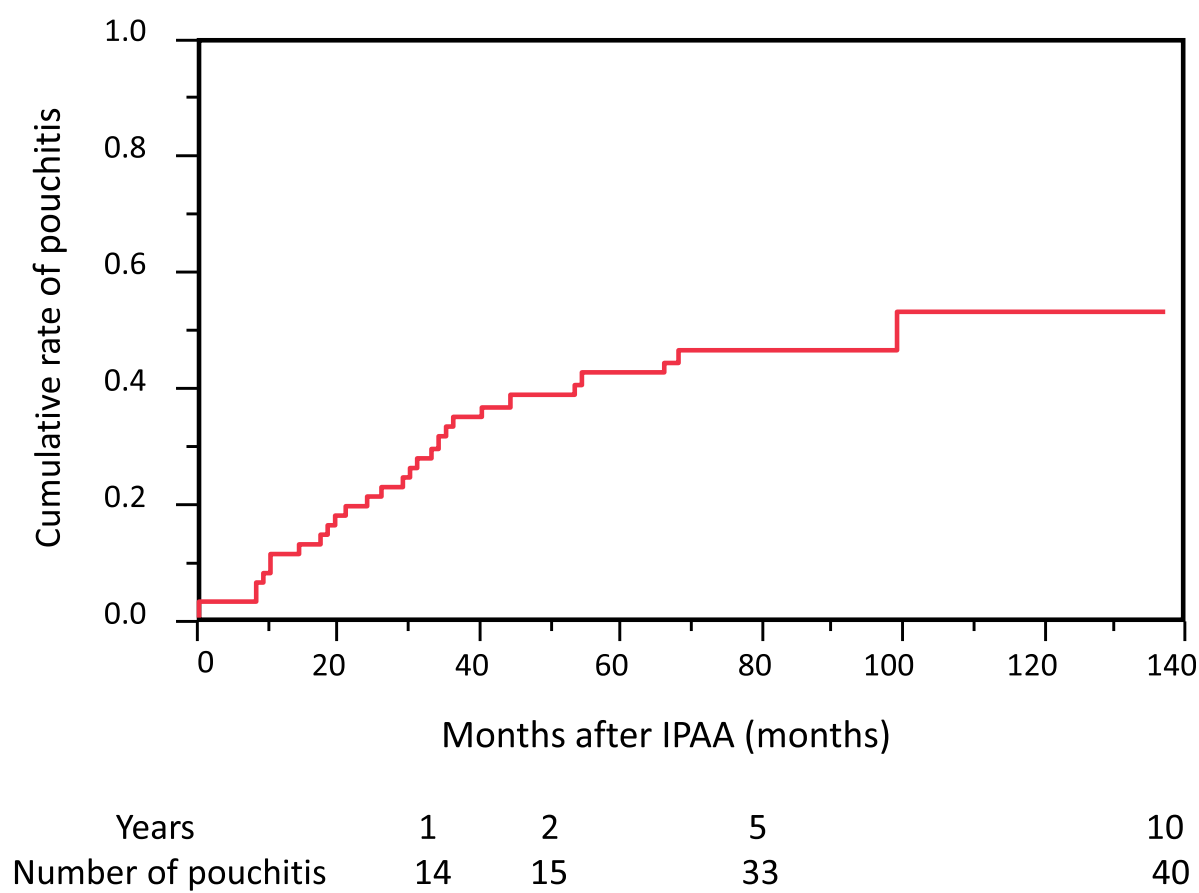

Fig. 1 Cumulative risk of developing pouchitis. Cumulative risk of developing pouchitis was $58.8 \%$ at the follow-up period (median 40 months (0-117 months))

extent of disease $[2,27]$, more severe preoperative clinical course, steroid dependency [28] and primary sclerosing cholangitis [29-31] have been reported. Other studies have reported that even pre- and postoperative use of biologics [32], steroid use before colectomy [26,
27], and postoperative use of nonsteroidal antiinflammatory drugs [25], have significantly correlated with pouchitis. However, in our study, these factors are no statistical difference between the pouchitis and no pouchitis groups. Therefore, additional risk factors or

Table 1 Clinicopathological factors of 68 patients with pouchitis

\begin{tabular}{|c|c|c|c|}
\hline Features & pouchitis $(n=40)$ & Non-pouchitis $(n=28)$ & $P$-value \\
\hline Age at IPAA (years) & $35.25 \pm 2.12$ & $33.00 \pm 2.34$ & 0.562 \\
\hline Gender (Male/female) & $23 / 17$ & $16 / 12$ & 0.976 \\
\hline Disease duration (years) & $8.54 \pm 1.35$ & $9.57 \pm 1.83$ & 0.635 \\
\hline Extent of colitis (total colitis/left-sided colitis, proctitis) & $30 / 10$ & $24 / 4$ & 0.282 \\
\hline Severity of colitis (severe/moderate or mild) & $6 / 34$ & $3 / 25$ & 0.607 \\
\hline Extra intestinal manifestation (yes/no) & $1 / 39$ & $1 / 27$ & 0.066 \\
\hline Total dasage of steroid before IPAA ( $\mathrm{g}$ ) & $15.66 \pm 3.41$ & $18.39 \pm 3.16$ & 0.268 \\
\hline Dosage of steroid per month just before surgery (mg) & $486.3 \pm 91.9$ & $449.8 \pm 83.8$ & 0.659 \\
\hline Immunomodulater use (yes/no) & $20 / 27$ & $21 / 16$ & 0.195 \\
\hline White blood cells $\left(\times 10^{3} / \mu \mathrm{l}\right)$ & $8.53 \pm 0.77$ & $8.96 \pm 0.62$ & 0.190 \\
\hline Hemoglobin (g/dl) & $10.9 \pm 0.41$ & $10.8 \pm 0.33$ & 0.717 \\
\hline Platelets $\left(\times 10^{4} / \mu \mathrm{l}\right)$ & $31.4 \pm 1.62$ & $35.4 \pm 1.97$ & 0.068 \\
\hline Albumin $(g / d l)$ & $3.50 \pm 0.11$ & $3.44 \pm 0.11$ & 0.644 \\
\hline C-reactive proten (mg/dl) & $2.16 \pm 0.75$ & $0.78 \pm 0.16$ & 0.426 \\
\hline Anastomotic leakage (yes/ no) & $5 / 35$ & $2 / 26$ & 0.474 \\
\hline
\end{tabular}

Categorical data were compared by chi-square test or Fisher's exact test

Bold text indicates statistical significance, ${ }^{*} p<0.05$

Abbreviations; IPAA lleal pouch anal anastomosis 
(a)

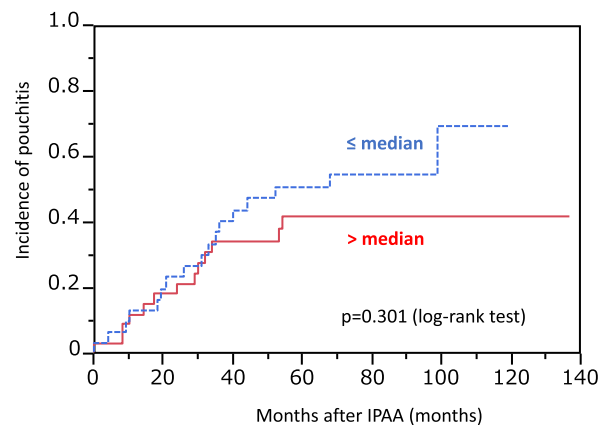

(b)

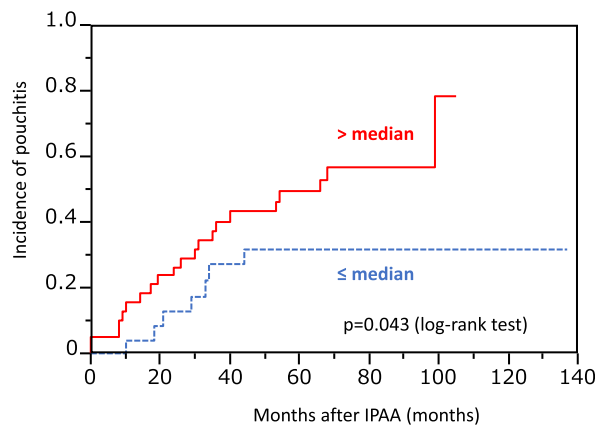

Fig. 2 The relationship between the cumulative incidence of pouchitis and IL-23A (a) and IFN- $(\mathbf{b})$. There was no association between IL-23A expression levels and the incidence of pouchitis $(p=0.301)$ (a). However, the patients with elevated IFN- $\gamma$ had a significantly higher incidence of pouchitis than those with low levels of IFN-Y $(p=0.043)$

Table 2 Relationship between $\mathrm{IFN}^{\dagger}-\gamma$ mRNA expression and preoperative clinicopathologic factors

\begin{tabular}{|c|c|c|c|c|}
\hline variable & & $n$ & mRNA expresion (mean \pm SD) & $P$-value \\
\hline \multirow[t]{2}{*}{ Gender } & Male & 39 & $0.99 \pm 0.13$ & 0.98 \\
\hline & Female & 29 & $1.19 \pm 0.22$ & \\
\hline \multirow[t]{2}{*}{ Age (years) } & $>32$ (median) & 34 & $0.97 \pm 0.14$ & 0.77 \\
\hline & $\leq 32$ & 34 & $1.16 \pm 0.19$ & \\
\hline \multirow[t]{2}{*}{ Disease duration } & $>7$ years (median) & 33 & $0.91 \pm 0.16$ & 0.25 \\
\hline & $\leq 7$ years & 35 & $1.17 \pm 0.18$ & \\
\hline \multirow[t]{2}{*}{ Extent of colitis } & Total colitis & 54 & $1.13 \pm 0.14$ & 0.16 \\
\hline & Left side colitis, proctitis & 14 & $0.64 \pm 0.08$ & \\
\hline \multirow[t]{2}{*}{ Severity of colitis } & Severe & 9 & $1.88 \pm 0.52$ & $0.04^{*}$ \\
\hline & Moderate, mild & 59 & $0.90 \pm 0.10$ & \\
\hline \multirow[t]{2}{*}{ Matts' grade } & 3,4 & 38 & $1.19 \pm 0.23$ & 0.18 \\
\hline & 1,2 & 28 & $0.85 \pm 0.12$ & \\
\hline \multirow[t]{2}{*}{ Extra intestinal manifestation } & Yes & 2 & $1.17 \pm 0.36$ & 0.38 \\
\hline & No & 66 & $1.02 \pm 0.12$ & \\
\hline \multirow[t]{2}{*}{ Total dasage of steroid before surgery (mg) } & $>7000$ & 39 & $0.95 \pm 0.13$ & 0.98 \\
\hline & $\leq 7000$ & 29 & $1.14 \pm 0.22$ & \\
\hline \multirow[t]{2}{*}{ Immunomodulator use } & Yes & 27 & $1.00 \pm 0.19$ & 0.90 \\
\hline & No & 41 & $1.04 \pm 0.16$ & \\
\hline \multirow[t]{2}{*}{ 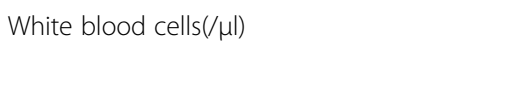 } & $>9000$ & 27 & $1.11 \pm 0.20$ & 0.45 \\
\hline & $\leq 9000$ & 41 & $0.97 \pm 0.15$ & \\
\hline \multirow[t]{2}{*}{$\mathrm{CRP}^{\ddagger}(\mathrm{mg} / \mathrm{dl})$} & $\geq 0.5$ & 32 & $1.11 \pm 0.16$ & 0.07 \\
\hline & $<0.5$ & 35 & $0.83 \pm 0.13$ & \\
\hline \multirow[t]{3}{*}{ Type of pouchitis } & No pouchitis & 38 & $1.04 \pm 0.40$ & 0.36 \\
\hline & Acute antibiotic-responsive pouchitis & 17 & $1.14 \pm 0.50$ & \\
\hline & Chronic antibiotic-refractory pouchitis & 13 & $0.90 \pm 0.30$ & \\
\hline
\end{tabular}

Categorical data were compared by chi-square test or Fisher's exact test

Bold text indicates statistical significance, ${ }^{*} p<0.05$

Abbreviations: ${ }^{\dagger}$ IFN Interferon; ${ }^{\ddagger} C R P$ C-reactive protein 
Table 3 Univariate and multivariate analysis of factors influencing pouchitis

\begin{tabular}{|c|c|c|c|c|c|c|}
\hline \multirow[t]{2}{*}{ Factors } & \multicolumn{3}{|l|}{ Univariate } & \multicolumn{3}{|c|}{ Multivariate } \\
\hline & Odd ratio & $95 \% \mathrm{Cl}$ & $p$ Value & Odd ratio & $95 \% \mathrm{Cl}$ & $p$ Value \\
\hline Gender (male vs female) & 1.21 & $0.46-3.24$ & 0.70 & & & \\
\hline Age ( $\leq 32$ years vs $<32$ years) & 0.48 & $0.17-1.27$ & 0.14 & & & \\
\hline Disease duration ( $\leq 7$ years vs $<7$ years) & 0.68 & $0.25-1.80$ & 0.44 & & & \\
\hline Extent of colitis (total colitis vs Left side colitis, proctitis) & 2.32 & $0.68-9.30$ & 0.18 & & & \\
\hline Severity of colitis (severe vs moderate, mild) & 1.68 & $0.40-8.59$ & 0.48 & & & \\
\hline Matts' grade $(3,4$ vs 1,2$)$ & 0.92 & $0.34-2.48$ & 0.88 & & & \\
\hline Total dosage of steroid before surgery ( $\leq 7000 \mathrm{mg}$ vs $<7000 \mathrm{mg}$ ) & 2.59 & $1.01-7.34$ & $0.04 *$ & 2.57 & $0.92-7.57$ & 0.06 \\
\hline Immunomodulator use (Yes vs No) & 2.16 & $0.81-5.94$ & 0.12 & & & \\
\hline IL-23A mRNA ( $\leq$ median vs $<$ median) & 0.55 & $0.68-1.45$ & 0.23 & & & \\
\hline IFN- $\gamma$ mRNA ( $\leq$ median vs $<$ median) & 3.05 & $1.11-8.92$ & $0.02^{*}$ & 3.04 & $1.08-9.12$ & $0.03^{*}$ \\
\hline
\end{tabular}

CI Confidence interval; mod. and well, moderately and well differentiated

Bold text indicates statistical significance, ${ }^{*} p<0.05$

aetiologic factors are needed to help predict which patients are at risk of pouchitis. In our study, only IFN- $\gamma$ mRNA expressions in patients who developed pouchitis were significantly higher than in patients without pouchitis $(p=0.043)$. In addition, multivariate analysis demonstrated that elevated IFN- $\gamma$ mRNA levels was an independent risk factor for the onset of pouchitis.

Pouchitis is a heterogeneous disorder with a combination of various underlying case. Acute pouchitis may be more attributable to dysbiosis in the ileal pouch. ADP, which is predominately microbially mediated, requires antibiotic therapy to maintain symptom remission. On the other hands, CARP may be a result of abnormal host immune response. Thus, a subgroup of patients with CARP does not respond to standard antibiotic therapy $[4,33-35]$. The treatment of choice is immunosuppressive therapy with a good response in the treatment of CARP and Crohn's pouchitis [36-38]. Therefore, when discussing risk factors or predicting factors for pouchitis, it is important to accurately phenotype patients with pouchitis. Our data suggest that IFN- $\gamma$ expression in ileal mucosa is slightly lower in patients with CARP than those with ADP, although not significant, since Crohn's pouchitis excluded in this study. Further large number study are needs to confirm the accurate correlation between IFN- $\gamma$ and immune mediated pouchitis.

IFN- $\gamma$, a cytokine secreted by activated T cells and natural killer (NK) cells, promotes inflammation by activating macrophages and upregulating the expression of cell adhesion molecules [39]. Furthermore, increased IFN- $\gamma$ production might be responsible for the tissue damage observed in pouchitis because IFN- $\gamma$ sustains cytotoxic reactions [40]. Signal transducer and activator of transcription (STAT)1 is part of the signaling pathway of other cytokines/growth factor receptors as well as be a hallmark of IFN- $\gamma$ receptor signal transduction [41-43].
Previous studies investigating activation and expression of nuclear factor-kappa B (NF-kB) and members of the STAT family has positive correlation with the activation of cytokine transcription factors in IBD [41-43]. Although increased NF- $\mathrm{kB}$ activation was more predominant in $\mathrm{CD}$ than in $\mathrm{UC}$, activation and expression of STAT1 were increased in UC compared with CD and normal controls [43-45]. A study investigating intracellular cytokine data reported that the pathophysiology of small-intestinal inflammation occurring after colectomy in patients with UC might be associated with a Th2 cytokine phenotype [46]. Additionally, there was a significant increase in the number of IFN $-\gamma$ producing mononuclear cells in patients with UC with pouchitis compared with UC patients without pouchitis [47]. Furthermore, there was a tendency towards increased levels of IFN- $\gamma$ and STAT1 in patients with UC, even without clinical and endoscopic evidence of pouchitis [48]. Of note, the normal pouch already indicated high levels of STAT1 expression and activation compared with normal preoperative ileum [44].

There are some limitations in this cohort. First, this retrospective study included a limited number of patients with geographical reason from a single cohort. We were unable to detect the genuine number of the patients with pouchitis. Therefore, the finding needs to be validated in a larger prospective cohort. Second, the short follow-up time duration was insufficient to evaluate incidence of pouchitis. Third, we analyzed specific 5 cytokines which might be suggested with incidence of pouchitis in this study. Therefore, further comprehensive analyses of ileal mucosal cytokines related with pouchitis are needed. Nevertheless, our findings suggest that IFN$\gamma$ expression in the normal ileal mucosa at the time of colectomy may be an important factor in the pathophysiology of pouchitis. However, further proteomics 
approach such as ELISA, immunohistochemical analysis or Western blot are needed to confirm the real IFN- $\gamma$ expression in the ileal mucosa.

\section{Conclusions}

Our data suggest that IFN- $\gamma$ expression in the normal ileal mucosa at the time of colectomy may be an important factor in the pathophysiology of pouchitis. Further research is required to determine the physiological role of IFN- $\gamma$.

\section{Abbreviations}

IBD: Inflammatory bowel diseases; Th: T helper; mRNA: Messenger RNA; IPAA: Ileal pouch anal anastomosis; UC: Ulcerative colitis; IFN: Interferon; CD: Crohn's disease; IL: Interleukin; ADP: Antibiotic dependent pouchitis; CARP: Chronic antibiotic refractory pouchitis; NF-kB: Nuclear factor-kappa B; STAT: Signal transducer and activator of transcription

\section{Acknowledgements}

We thank Edanz Group (www.edanzediting.com/ac) for editing a draft of this manuscript.

\section{Authors' contributions}

Conception: TK, MK, KU; design of the work: TK, MK, YO; the acquisition of data: YO, SK, KU; analysis of data: TK, MK; interpretation of data: TK, MK, YT; drafting of the work: TK, YT, KU, MK. All authors have read and approved the manuscript.

\section{Funding}

This study has received a research grant from Japanese Society for Palliative Medicine and Mie Medical Research Foundation.

\section{Availability of data and materials}

All data generated or analyzed during this study are included in this published article.

\section{Ethics approval and consent to participate}

The protocol for this research project has been approved by a suitably constituted Ethics Committee of the Institutional Review Board of Mie University Hospital, and it conforms to the provisions of the Declaration of Helsinki. All informed consent was obtained from the subjects and respective guardians with written.

\section{Consent for publication}

Not applicable.

\section{Competing interests}

The authors declare that they have no competing interests

\section{Received: 11 December 2019 Accepted: 11 August 2020}

Published online: 18 August 2020

\section{References}

1. Coffey JC, Rowan F, Burke J, Dochery NG, Kirwan WO, O'Connel RP. Pathogenesis of and unifying hypothesis for idiopathic pouchitis. Am J Gastroenterol. 2009:104:1013-23.

2. Hashavia E, Dotan I, Rabau M, Klausner JM, Halpern Z, Tulchinsky H. Risk factors for chronic pouchitis after ileal pouch-anal anastomosis: a prospective cohort study. Colorectal Dis. 2012;14:1365-71.

3. Araki T, Kawamura M, Tanaka K, et al. FK506-binding protein 5 mRNA levels in lleal mucosa are associated with Pouchitis in patients with ulcerative colitis. Dig Dis Sci. 2015;60(6):1617-23.

4. Hata K, Ishihara S, Nozawa H, et al. Pouchitis after ileal pouch-anal anastomosis in ulcerative colitis: diagnosis, management, risk factors, and incidence. Dig Endosc. Jan 2017;29(1):26-34.

5. Mosmann TR, Cherwinski H, Bond MW, Giedlin MA, Coffman RL. Two types of murine helper $T$ cell clone. I. Definition according to profiles of lymphokine activities and secreted proteins. J Immunol. 2005;175(1):5-14.
6. Parronchi $P$, Romagnani $P$, Annunziato F, et al. Type 1 T-helper cell predominance and interleukin-12 expression in the gut of patients with Crohn's disease. Am J Pathol. 1997;150(3):823-32.

7. Breese E, Braegger CP, Corrigan CJ, Walker-Smith JA. TT. M. Interleukin-2and interferon-y-secreting T cells in normal and diseased human intestinal mucosa. Immunology. 1993;78(1):127-31.

8. Fuss IJ, Neurath M, Boirivant M, et al. Disparate CD4+ lamina propria (LP) lymphokine secretion profiles in inflammatory bowel disease. Crohn's disease LP cells manifest increased secretion of IFN-gamma, whereas ulcerative colitis LP cells manifest increased secretion of IL-5. J Immunol. 1996;157(3):1261-70.

9. Oppmann B, Lesley R, Blom B, et al. Novel p19 protein engages IL-12p40 to form a cytokine, IL-23, with biological activities similar as well as distinct from IL-12. Immunity. 2000;13(5):715-25

10. Aggarwal S, Ghilardi N, Xie MH, de Sauvage FJ, Gurney AL. Interleukin-23 promotes a distinct CD4 T cell activation state characterized by the production of interleukin-17. J Biol Chem. 2003:278(3):1910-4.

11. Yen D, Cheung J, Scheerens H, et al. IL-23 is essential for T cell-mediated colitis and promotes inflammation via IL-17 and IL-6. J Clin Invest. 2006; 116(5):1310-6.

12. Bettelli $E$, Oukka $M$, Kuchroo VK. T(H)-17 cells in the circle of immunity and autoimmunity. Nat Immunol. 2007;8(4):345-50.

13. Maloy KJ. The Interleukin-23 / Interleukin-17 axis in intestinal inflammation. J Intern Med. 2008;263(6):584-90.

14. Fujino S, Andoh A, Bamba S, et al. Increased expression of interleukin 17 in inflammatory bowel disease. Gut. 2003:52(1):65-70.

15. Nielsen $\mathrm{OH}$, Kirman I, Rüdiger N, Hendel J, Vainer B. Upregulation of interleukin-12 and -17 in active inflammatory bowel disease. Scand J Gastroenterol. 2003;38(2):180-5.

16. Olsen T, Rismo R, Cui G, Goll R, Christiansen I, Florholmen J. TH1 and TH17 interactions in untreated inflamed mucosa of inflammatory bowel disease, and their potential to mediate the inflammation. Cytokine. 2011:56(3):633-40.

17. Paolo G, Massimo C, Andrea B, et al. Macrophage subpopulations and interleukin-1ß tissue levels in pelvic ileal pouch pouches. Eur J Gastroenterol Hepatol. 1994;6:217-22.

18. Reinecker HC, Steffen M, Witthoeft T, et al. Enhanced secretion of tumor necrosis factor alpha, IL-6 and II-1ß by isolated lamina propria mononuclear cells from patients with ulcerative colitis and Crohn's disease. Clin Exp Immunol. 1993;94:174-81.

19. Shen B, Achkar JP, Connor JT, et al. Modified pouchitis disease activity index: a simplified approach to the diagnosis of pouchitis. Dis Colon Rectum. 2003;46(6):748-53.

20. Gasche C, Scholmerich J, Brynskov J, et al. A simple classification of Crohn's disease: report of the working Party for the World Congresses of gastroenterology, Vienna 1998. Inflamm Bowel Dis. Feb 2000;6(1):8-15.

21. Silverberg MS, Satsangi J, Ahmad T, et al. Toward an integrated clinical, molecular and serological classification of inflammatory bowel disease: report of a working party of the 2005 montreal world congress of gastroenterology. Can J Gastroenterol. 2005:19(Suppl A):5A-36A.

22. Seril DN, Yao Q, Lashner BA, Shen B. Autoimmune features are associated with chronic antibiotic-refractory pouchitis. Inflamm Bowel Dis. 2015;21(1):110-20.

23. Lohmuller JL, Pemberton JH, Dozois RR, Istrup D. Heerden Jv. Pouchitis and extraintestinal manifestations of inflammatory bowel disease after ileal pouch-anal anastomosis. Ann Surg. 1990;211:622-9.

24. Hata K, Watanabe $T$, Shinozaki M, Nagawa $H$. Patients with extraintestinal manifestations have a higher risk of developing pouchitis in ulcerative colitis: multivariate analysis. Scand J Gastroenterol. 2003;38:1055-8.

25. Achkar JP, Al-Haddad M, Lashner B, et al. Differentiating risk factors for acute and chronic pouchitis. Clin Gastroenterol Hepatol. 2005;3:60-6.

26. Fleshner $P$, Ippoliti A, Dubinsky $M$, et al. A prospective multivariate analysis of clinical factors associated with pouchitis after ileal pouch-anal anastomosis. Clin Gastroenterol Hepatol. 2007;5:952-8.

27. Lipman JM, Kiran RP, Shen B, Remzi F, Fazio WW. Perioperative factors during ileal pouch-anal anastomosis predict pouchitis. Dis Colon Rectum. 2011;54:311-7

28. Kalkan IH, Dağli Ü, Önder FO, et al. Evaluation of preoperative predictors of development of pouchitis after ileal-pouch-anastomosis in ulcerative colitis. Clin Res Hepatol Gastroenterol. 2012:36:622-7.

29. Penna C, Dozois R, Tremaine W, et al. Pouchitis after ileal pouch-anal anastomosis for ulcerative colitis occurs with increased frequency in patients with associated primary sclerosing cholangitis. Gut. 1996;38:234-9. 
30. Hoda KM, Collins JF, Knigge KL, Deveney KE. Predictors of pouchitis after ileal pouch-anal anastomosis: a retrospective review. Dis Colon rectum. 2008:51:554-60.

31. Wasmuth HH, Tranø G, Endreseth BH, Wibe A, Rydning A, Myrvold HE. Primary sclerosing cholangitis and extraintestinal manifestations in patients with ulcerative colitis and ileal pouch-anal anastomosis. J Gastrointest Surg. 2010;14:1099-104

32. Shen $B, Y u C$, Lian $L$, et al. Prediction of late-onset pouch failure in patients with restorative proctocolectomy with a nomogram. J Crohns Colitis. 2012; 6:198-206.

33. Hurst RD, Chung TP, Rubin M, Michelassi F. The implications of acute pouchitis on the long-term functional results after restorative proctocolectomy. Inflamm Bowel Dis. Nov 1998;4(4):280-4.

34. Mowschenson PM, Critchlow JF, Peppercorn MA. lleoanal pouch operation: long-term outcome with or without diverting ileostomy. Arch Surg. 2000; 135(4):463-5 discussion 465-466.

35. Shen B. Diagnosis and treatment of patients with pouchitis. Drugs. 2003; 63(5):453-61.

36. Haveran LA, Sehgal R, Poritz LS, McKenna KJ, Stewart DB, Koltun WA. Infliximab and/or azathioprine in the treatment of Crohn's disease-like complications after IPAA. Dis Colon rectum. Jan 2011;54(1):15-20.

37. Sedano R, Nuñez P, Quera R. Diagnostic and management approach to pouchitis in inflammatory bowel disease. Arq Gastroenterol. 2020;57(1):100-6.

38. Shen B. Crohn's disease of the ileal pouch: reality, diagnosis, and management. Inflamm Bowel Dis. 2009;15(2):284-94.

39. Dijkmans R, Billiau A. Interferon gamma: a master key in the immune system. Curr Opin Immunol. 1998;1(2):269-74.

40. Fink S, de la Barrera S, Minnucci F, Valdez R, Baliña LM, Sasiain MC. IFN-ץ, IL6 and IL-4 modulate M. leprae- or PPD-specific cytotoxic T cells in leprosy patients. Scand I Immunol. 1993;38:551-8.

41. Nikolaus S, Bauditz J, Gionchetti P, Witt C, Lochs H, Schreiber S. Increased Secrection of proinflammatory cytokines by polymorphonuclear neutrophils regulation by Interleukin 10 in inflammatory bowel disease. Gut. 1998;42:470-6.

42. Rogler $G$, Brand $K$, Vogl D, et al. Nuclear factor kappa B is activated in macrophages and epithelial cells of inflamed intestinal mucosa. Gastroenterology. 1998;115:357-69.

43. Schreiber S, Nikolaus S, Hampe J. Activation of Nuclear Factor kappa B in inflammatory bowel disease. Gut. 1998:42:477-84.

44. Kühbacher T, Gionchetti P. Hampe J, et al. Activation of signal-transducer and activator of transcription 1 (STAT1) in pouchitis. Clin Exp Immunol. 2001;123(3):395-401

45. Schreiber S, Rosenstiel P, Hampe J, et al. Activation of signal transducer and activator of transcription (STAT) 1 in human chronic inflammatory bowel disease. Gut. 2002;51(3):379-85.

46. Akitake R, Nakase $H$, Tamaoki M, Ueno S, Mikami S, Chiba T. Modulation of Th1/Th2 balance by infliximab rescues postoperative occurrence of smallintestinal inflammation associated with ulcerative colitis. Dig Dis Sci. 2010; 55(6):1781-4..

47. Stallmach A, Schäfer F, Hoffmann S, et al. Increased state of activation of CD4 positive $T$ cells and elevated interferon gamma production in pouchitis. Gut. 1998:43(4):499-505.

48. Leal RF, Ayrizono ML, Milanski M, et al. Activation of signal transducer and activator of transcription-1 (STAT-1) and differential expression of interferon-gamma and anti-inflammatory proteins in pelvic ileal pouches for ulcerative colitis and familial adenomatous polyposis. Clin Exp Immunol. 2010;160(3):380-5

\section{Publisher's Note}

Springer Nature remains neutral with regard to jurisdictional claims in published maps and institutional affiliations.

Ready to submit your research? Choose BMC and benefit from:

- fast, convenient online submission

- thorough peer review by experienced researchers in your field

- rapid publication on acceptance

- support for research data, including large and complex data types

- gold Open Access which fosters wider collaboration and increased citations

- maximum visibility for your research: over $100 \mathrm{M}$ website views per year

At $\mathrm{BMC}$, research is always in progress.

Learn more biomedcentral.com/submissions 